\title{
The Experimental Study of the Strength Characteristics of Blast Furnace Water Quenching Slag-High Sulfur Tailings Filling
}

\author{
WANG Fu-lin ${ }^{1, a}$, WANG Zhong-kang ${ }^{1, b}$, YANG Shi-jiao ${ }^{1, c^{*}}$, TANG Zi-an ${ }^{2, d}$, LIU \\ $\mathrm{Jie}^{1, \mathrm{e}}$ \\ ${ }^{1}$ School of Nuclear Resources Engineering, University of South China, Hengyang, 421001, China \\ ${ }^{2}$ Yiyang Central Hospital, Yiyang, 413000, China \\ awangfl2009@126.com, b'wangzhongkang@126.com, ${ }^{\mathrm{c}}$ cute1088@sina.com, \\ d1965557308@qq.com, 616756003@qq.com \\ * corresponding author
}

\begin{abstract}
Keywords: High sulfur tailings; Blast furnace water quenching slag; Filling; Uniaxial compressive strength

Abstract. In order to solve the problem of low strength and disintegrate easily using ordinary Portland cement-high sulfur tailings filling, we used blast furnace water quenching slag instead of Portland cement which was regarded as cement material to manufacture whole tailings paste for underground filling. We manufactured filling with blast furnace water quenching slag-high sulfur tailings and ordinary Portland cement on the base of analyzing the physicochemical property of whole tailings and blast furnace water quenching slag. Then we manufactured the standard test blocks to cure, and studied the strength of filling with different cement materials in accordance with uniaxial compressive test by the application of the machine of DYE-300 single shaft material test. Compared with cement filling, experimental results show that the strength of blast furnace water quenching slag, early stage or late stage, has a higher strength. And, moreover, it can solve the disintegrating problem caused by ordinary Portland cement-high sulfur tailings filling in the late stage.
\end{abstract}

\section{Introduction}

The whole tailings paste filling is the most effective way to realize the development of mining industry with little tailings or without tailings, which is also the most promising development direction to realize utilization and harmlessness of tailings in mine ${ }^{[1]}$. However, tailings of part of mental mines contains high content of sulfur, filling has some problems when we use ordinary Portland cement as cement material to fill the whole tailings paste, such as low strength of filling in the early stage, large consumption of cement, high cost of filling. With curing time delay, the whole tailings paste filling expands gradually lead to the strength of filling reducing even causing disintegration ${ }^{[2]}$. It brings about hidden trouble of safety production to mine, and affects the popularization and application of the whole tailings paste filling in this kind of underground mining.

In order to reduce the cost of the whole tailings paste filling and the requirement of the strength, experts and scholars at home and abroad seek cement material which has wide raw material sources, good gelling and low price. The study of blast furnace water quenching slag and fly ash is the most popular among them. Blast furnace water quenching slag has the potential gelling activity, and we could motivate it through mechanical and chemical ways. Dong $\mathrm{Lu}{ }^{[3]}$ wants to solve technical problems of whole tailings-cement filling by using water quenching slag as the main cement material, such as low strength, high viscosity of filling slurry, and high cost. Wang Jian ${ }^{[4]}$ wants to solve the problem that mine requests fillings has higher strength in the early stage by using water quenching slag as cement material. The application of blast furnace water quenching slag indicates it's a good kind of cement material, and it has such obvious advantages that it contains low cost, wide source, meeting different requirements of whole tailings filling in mine filling ${ }^{[5 \sim 9]}$. Zhang Qin-li used fly ash as part of cement material to fill paste using cement-fly ash-whole tailings with sulfur for the adverse impact of tailings containing sulfur on the whole tailings paste filling. They solved the problem that filling damage caused by the volume expansion successfully, achieved good filling effect. The 
principle is that fly ash providing additional space for expansion of filling is a kind of porous material, so as to ensure disintegration won't happen due to the expansion of filling in the late stage.

Blast furnace water quenching slag has the potential gelling activity, wide source, low cost, which is a good replacement of cement material. According to the successful experience of using fly ash as cement material to deal with high sulfur tailings, we conduct a study that replacing cement with blast furnace water quenching slag as cement material cements high sulfur tailings, which will have positive significance to promote the whole tailings paste filling ${ }^{[2,10]}$.

\section{The Physicochemical Property of Filling}

We selected whole tailings from discharging mouth of a mine factory and analyzed the physicochemical property of it. The particle size composition is shown in Fig. 1, and the volume average particle size is $101.781 \mu \mathrm{m}$.

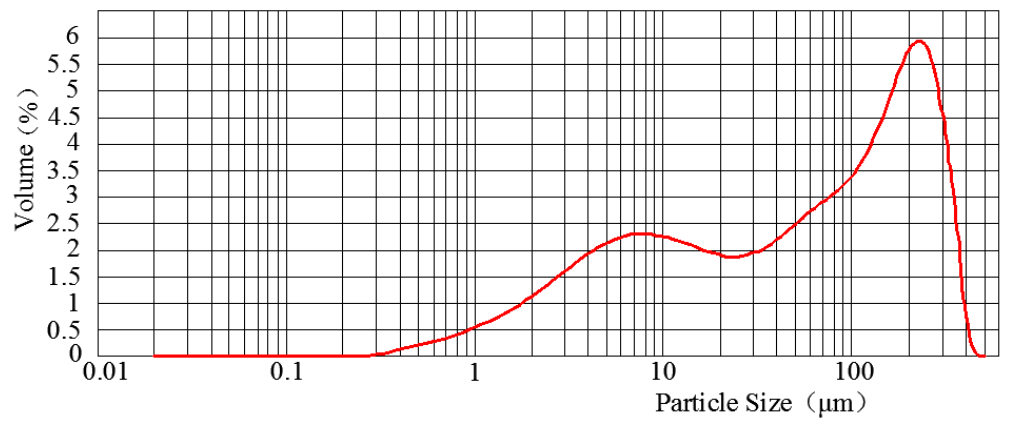

Fig. 1 Cumulative distribution of particle size

The analysis result of chemical composition of whole tailings is shown in Table 1, and sulfur takes up $8.25 \% \sim 10.30 \%$ in total tailings, belonging to high sulfur tailings. It has certain gelling property with proper sulfur and can replace cement partly to save the cost of filling. But high sulfur content will influence the strength of filling in the late stage for whole tailings filling adverse.

Table 1 Fluorescence test results of tailing samples

\begin{tabular}{cccc}
\hline element & content/\% & element & content/\% \\
\hline $\mathrm{O}$ & 48.0 & $\mathrm{Fe}$ & 8.264 \\
$\mathrm{Na}$ & 0.178 & $\mathrm{Si}$ & 15.52 \\
$\mathrm{Mg}$ & 6.383 & $\mathrm{~S}$ & $8.25 \sim 10.30$ \\
$\mathrm{Al}$ & 4.16 & $\mathrm{~K}$ & 1.3 \\
$\mathrm{Ca}$ & 13.71 & & \\
\hline
\end{tabular}

We chose blast furnace water quenching slag (adding required activator) for experiment from a factory, and the main chemical component is shown in Table 2.

Table 2 Chemical composition of blast furnace water quenching slag

\begin{tabular}{ccccccccc}
\hline Composition & $\mathrm{SiO}_{2}$ & $\mathrm{Al}_{2} \mathrm{O}_{3}$ & $\mathrm{Fe}_{2} \mathrm{O}_{3}$ & $\mathrm{CaO}$ & $\mathrm{MgO}$ & $\mathrm{SO}_{3}$ & $\mathrm{TiO}_{2}$ & others \\
\hline content $/ \%$ & 37.2 & 15.8 & 2.3 & 38.92 & 3.6 & 0.23 & 1.6 & 0.35 \\
\hline
\end{tabular}

The respective proportion of $\mathrm{CaO}$ and $\mathrm{Al}_{2} \mathrm{O}_{3}$ in blast furnace water quenching slag is $38.92 \%$ and $15.8 \%$ with a high content. The density of blast furnace water quenching slag whose water content is less than $1 \%$ is $310 \mathrm{t} / \mathrm{m}^{3}$, and the specific surface area is $400 \mathrm{~m}^{2} / \mathrm{kg}$.

Blast furnace water quenching slag is one of industrial solid wastes in the course of ironmaking. It can be transformed into loosened granulous slag by the cooling system coming from water, which is also called water-granulated slag. A large proportion of people agree with the views that the mixture of silicate glass and phase constituent is significant for the activity of blast furnace water quenching 
slag, such as $\mathrm{SiO}_{2}, \mathrm{CaO}$ and $\mathrm{Al}_{2} \mathrm{O}_{3}{ }^{[11 \sim 12]}$. We could motivate it through mechanical excitation and chemical way to achieve the potential hydration of blast furnace water quenching slag. Mechanical excitation is usually to levigate blast furnace water quenching slag for the specific surface area over $400 \mathrm{~m}^{2} / \mathrm{kg}$. Chemical way usually inspires the potential hydraulic and curing ability by using alkali or sulfate as medicament, such as $\mathrm{Ca}(\mathrm{OH})_{2}$ and $\mathrm{Na}_{2} \mathrm{SO}_{4}$ or $\mathrm{K}_{2} \mathrm{SO}_{4}$. Limenez has used several kinds of activators to inspire slag, such as $\mathrm{Ca}(\mathrm{OH})_{2}$ and $\mathrm{CaSO}_{4} \cdot 2 \mathrm{H}_{2} \mathrm{O}$, and the result shows that the strength of filling improved obviously.

\section{The Experimental Study on Compressive Strength of Filling}

We carried out respective tests of the strength of cement filling with whole tailings-cement and total tailings-blast furnace water quenching slag, in which we used ordinary Portland cement (P.O.42.5). According to ratio containing of each cement-sand referring 1:4, 1:6, 1:8 given by experimental group and control respectively, we accordingly provided 18 groups of filling slurry whose weight concentration were $66 \%, 68 \%$ and $70 \%$. Then we also accordingly made standard compressive test blocks whose volume were $70.7 \mathrm{~mm} \times 70.7 \mathrm{~mm} \times 70.7 \mathrm{~mm}$. After removing the mould, standard curing was conducted, and we used the machine of DYE-300 single shaft material test to test uniaxial compressive strength of filling blocks by means of standard curing respectively lasting for 3 days, 7 days, 14 days and 28 days. The experimental results are shown in Table 3.

Table 3 Strength index of full tailings filling of the cement and blast furnace water quenching slag

\begin{tabular}{|c|c|c|c|c|c|c|c|}
\hline \multirow[b]{2}{*}{$\begin{array}{l}\text { cement- } \\
\text { sand ratio }\end{array}$} & \multirow{2}{*}{$\begin{array}{c}\text { weight } \\
\text { concentration } \\
1 \%\end{array}$} & \multicolumn{2}{|c|}{$\begin{array}{c}\text { compressive strength } \\
7 \mathrm{~d} / \mathrm{MPa} \\
\end{array}$} & \multicolumn{2}{|c|}{$\begin{array}{c}\text { compressive strength } \\
28 \mathrm{~d} / \mathrm{MPa} \\
\end{array}$} & \multicolumn{2}{|c|}{$\begin{array}{c}\text { compressive strength } \\
60 \mathrm{~d} / \mathrm{MPa} \\
\end{array}$} \\
\hline & & cement & $\begin{array}{c}\text { blast furnace } \\
\text { water } \\
\text { quenching slag }\end{array}$ & cement & $\begin{array}{c}\text { blast furnace } \\
\text { water } \\
\text { quenching slag }\end{array}$ & cement & $\begin{array}{c}\text { blast furnace } \\
\text { water } \\
\text { quenching slag }\end{array}$ \\
\hline $1: 4$ & $\begin{array}{l}66 \\
68 \\
70\end{array}$ & $\begin{array}{l}0.531 \\
0.671 \\
0.755\end{array}$ & $\begin{array}{l}3.74 \\
3.98 \\
4.63\end{array}$ & $\begin{array}{l}0.933 \\
1.257 \\
1.639\end{array}$ & $\begin{array}{l}4.65 \\
4.87 \\
6.70\end{array}$ & $\begin{array}{l}1.269 \\
1.435 \\
1.803\end{array}$ & $\begin{array}{l}4.77 \\
4.85 \\
6.81\end{array}$ \\
\hline $1: 6$ & $\begin{array}{l}66 \\
68 \\
70\end{array}$ & $\begin{array}{l}0.267 \\
0.327 \\
0.409\end{array}$ & $\begin{array}{l}2.15 \\
2.44 \\
3.11\end{array}$ & $\begin{array}{l}0.497 \\
0.675 \\
0.915\end{array}$ & $\begin{array}{l}3.2 \\
3.4 \\
4.5\end{array}$ & $\begin{array}{l}0.593 \\
0.810 \\
1.033\end{array}$ & $\begin{array}{l}3.35 \\
3.54 \\
4.82\end{array}$ \\
\hline $1: 8$ & $\begin{array}{l}66 \\
68 \\
70\end{array}$ & $\begin{array}{l}0.175 \\
0.217 \\
0.266\end{array}$ & $\begin{array}{l}1.2 \\
1.5 \\
1.9\end{array}$ & $\begin{array}{l}0.348 \\
0.518 \\
0.632\end{array}$ & $\begin{array}{l}1.73 \\
2.20 \\
2.76\end{array}$ & $\begin{array}{l}0.403 \\
0.614 \\
0.727\end{array}$ & $\begin{array}{l}1.80 \\
2.22 \\
2.77\end{array}$ \\
\hline
\end{tabular}

We analyzed respectively whole tailings-cement and whole tailings-blast furnace water quenching slag both with the concentration of $66 \%$ which cement-sand ratio was 1:6 and 1:8, and achieved the strength characteristic curve of curing time-filling strength, shown in Fig. 2, Fig. 3.

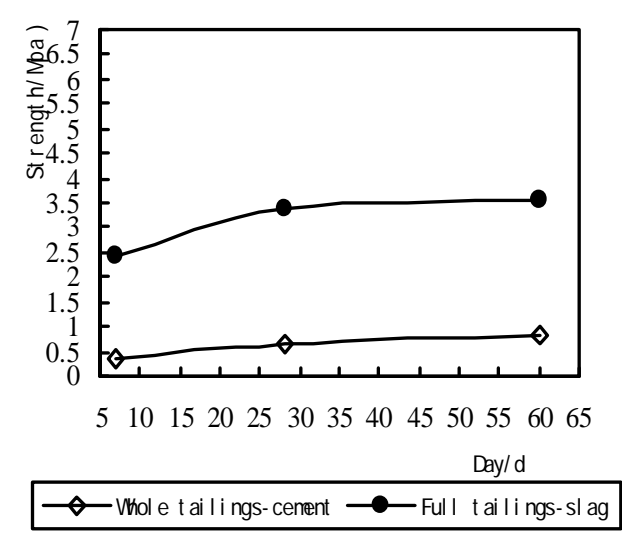

Fig. 2 Strength filling curve of cement-sand ratio characteristics of $1: 6$

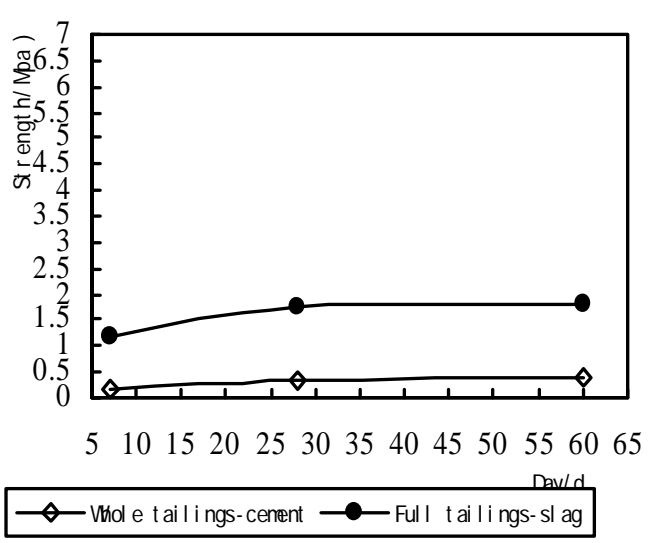

Fig. 3 Strength filling curve of cement-sand ratio characteristics of $1: 8$ 


\section{The Analysis of Experimental Result}

According to the analysis of experimental results from Table 3, Fig. 2, and Fig. 3, the strength of filling using blast furnace water quenching slag as cement material improved a lot in the both early stage and late stage at the same weight concentration and cement-sand ratio. Compared with cement, the uniaxial compressive strength of filling with blast furnace water quenching slag curing 7 days grew 2.3Mpa on an average, and curing 28 days grew $2.7 \mathrm{Mpa}$ on an average, and curing 60 days grew 2.9Mpa on an average.

We tracked the filling test blocks curing 60 days with whole tailings-cement and whole tailings-blast furnace water quenching slag respectively. The filling test blocks with cement cracked on surface and had the tendency to disintegrate. However, the filling test blocks with blast furnace water quenching slag appeared completely on surface.

Whole high sulfur tailings reacts hydration reaction in filling slurry, as follows:

$$
\begin{gathered}
\mathrm{CaO}+\mathrm{H}_{2} \mathrm{O} \rightarrow \mathrm{Ca}(\mathrm{OH})_{2} \\
\mathrm{Al}_{2} \mathrm{O}_{3}+3 \mathrm{Ca}(\mathrm{OH})_{2}+6 \mathrm{H}_{2} \mathrm{O} \rightarrow 3 \mathrm{CaO} \cdot \mathrm{Al}_{2} \mathrm{O}_{3} \cdot 6 \mathrm{H}_{2} \mathrm{O}
\end{gathered}
$$

During the process, $\mathrm{SO}_{4}{ }^{2-}$ in slurry often combines with $\mathrm{Ca}^{2+}$ to generate $\mathrm{CaSO}_{4}$ which is slightly soluble in water, then $\mathrm{CaSO}_{4}$ and $3 \mathrm{CaO} \bullet \mathrm{Al}_{2} \mathrm{O}_{3} \cdot 6 \mathrm{H}_{2} \mathrm{O}$ reacts to generate minerals ${ }^{[13 \sim 14]}$, such as three sulfur hydrated calcium aluminate sulfur with high combined water $\left(3 \mathrm{CaO} \bullet \mathrm{Al}_{2} \mathrm{O}_{3} \bullet 3 \mathrm{CaSO}_{4} \bullet 32 \mathrm{H}_{2} \mathrm{O}\right)$. Volume expansion will happen in the late stage of curing paste filling in this kind of mineral, which will cause the damage of the structure of filling, the reducing of its strength, and the disintegrating of its result in destroying the structure completely in extreme situation. Blast furnace water quenching slag inspired by sulfate in the reaction of whole tailings-blast furnace water quenching slag generates spongy porous structure in the process of hydration, and calcium sulfoaluminate hydrates (ettringite) from high sulfur tailings fill porous structure. Calcium sulfoaluminate hydrates extrude pore structure after volume expansion, and bring a compacting effect to the pore structure, improving the strength of filling greatly. Generated structure from blast furnace quenching slag could withstand pressure caused by expansion of Calcium sulfoaluminate hydrates, and provide additional compensating space for volume expansion. So it increases the strength of filling and ensures the integrity of filling, and solves the problem well that high sulfur tailings results in volume expansion, strength reduction even disintegration.

\section{Conclusions}

(1) When using high sulfur tailings-ordinary Portland cement does paste filling, the volume expansion of three sulfur hydrated calcium aluminate sulfur with high combined water in the late stage of curing filling results in strength reduction even disintegration. The strength of filling using blast furnace water quenching slag as cement material has improved obviously, early stage and late stage, and solves the problem well that high sulfur tailings is bad for the whole tailings paste filling. (2) Sulfate can inspire the cementitious activity of blast furnace water quenching slag in high sulfur tailings. The spongy porous structure of filling using blast furnace water quenching slag could withstand pressure caused by expansion of sulfate hydrated minerals, and provide space for volume expansion, which will make the structure of filling denser and the strength higher. 


\section{Acknowledgement}

This research was financially supported by the National Science Foundation (NO.50974076), the Scientific Research Project of Hunan Province Department of Education (NO.14C0959) and the Postgraduate Research Innovation Project of Hunan Province (NO.2015SCX14).

\section{References}

[1] Qundi Yuan, Technological research of a new type plaster filling process, Metal Mine, 11(2009)278-283 . ( In Chinese )

[2] Qinli Zhang, Qian Kang, Fuguo Xiao, Key technology of cemented backfilling with high viscosity sulfur-content tailings, Metal Mine, 11(2010)39-42. ( In Chinese )

[3] Lu Dong, Qian Gao, Shiqing Nan, Performance and hydration mechanism of new super fine cemented whole-tailings backfilling materials, Journal of Central South University (Science and Technology), 44(2013)1571-1577. ( In Chinese )

[4] Jian Wang, Xianjun Lv, Shugang Hu, Application on low cost and high early strength material for paste filling, Metal Mine, 11(2009)6-9. ( In Chinese )

[5] Shanshan Xue, Lijie Guo, Xin Li, Influence of hydration products on mechanical performance of composite cementitious material, Bulletin Of The Chinese Ceramic Society, 1(2014)37-42. ( In Chinese )

[6] Yang Lu, Gen Li, Xueke Xie, Research progress on the influence of slag on cement hydration, Bulletin Of The Chinese Ceramic Society, 12(2013)2528-2532. ( In Chinese )

[7] Huansha He, Qian Gao, Wei Wei, Experiment and improvement on the performances of a new cementing material used for unclassified tailings filling, Mining R\&D, 2012, 4(2012)11-14. ( In Chinese )

[8] Kefeng Han, Application of fine grounded granulated blast-furnace slag in whole tailings cementation filling, Metal Mine, 7(2001)45 47. ( In Chinese )

[9] Weidong Ma, Desheng Gu, Jie Wang, High-performance gelled material from water quenching slag for backfilling, Nonferrous Metals, 1(2006)86-88. ( In Chinese )

[10] Jianfeng Gao, Experiment and practice of sulfur-containing tailings cementation filling applied in underground mined-out area, Nonferrous Metals ( Mining Section ), 66(2014) 9-11. ( In Chinese )

[11] Maohui Li, Qian Gao, Youtuan Wang, Pilot tests on the new cementing materials preparation for filling in Sijiaying Iron Mine, Metal Mine, 8(2013)153-156. ( In Chinese )

[12] Benzaazoua M, Fiset J F, Bussiere B, Sludge recycling within cemented paste backfill: Study of the mechanical and leachability properties, Minerals Engineering, 29(2006) 420-426.

[13] Shiguo Chen, Yongmin Zhou, Investigation on Ye'elimite hydration in gypsum and calcium hydroxide solution, Bulletin Of The Chinese Ceramic Society, 3(2014)487-492. ( In Chinese )

[14] Yu Li, Henghu Sun, Yonghong Zhao, Research of formation mechanism on cementitious reactivity of water-cooled slag, The Chinese Journal of Process Engineering, 7(2007)79-84. ( In Chinese ) 